\title{
Assessment of Hydrological Inspection Using Development Low-Cost Boat Application in University Sultan Zainal Abidin (UniSZA) Lake, Terengganu, Malaysia
}

\author{
Mohd Khairul Amri Kamarudin, Mohammad Faezul Hakim Mustapha, Noorjima Abd Wahab, \\ Muhammad Hafiz Md. Saad, Mohd Ekhwan Toriman, Firdaus Mohd Hamzah, Mohd Armi \\ Abu Samah, Mohd Syaiful Nizam Abu Hassan, Siti Nor Aisyah Md Bati
}

\begin{abstract}
Unmanned vehicles may provide less time consume and cost-effective methods of gathering hydrographic survey data compared to traditional, manned survey vessels. A remote-controlled Unmanned Surface Vehicle (USV) was outfitted with range finder, depth transducer, and velocity current meter for the purpose of conducting a hydro survey. The purpose of study to describes a project for the development of Unmanned Survey Vessel (USV) platform useful for hydrological survey. The control unit includes a motor control system, communication equipment, and a simple radio control system installed to enables an operator to remotely control the boat. The motor radio control system, the measurement equipment (sonar depth, current meter, range finder) used in data collecting activities. The result showed the validation values of Hydro Survey Boat Version 1 and Hydro Survey Boat Version 2, the estimated validation of river discharge $(Q)$ recorded $0.0373 \mathrm{~m} 3 / \mathrm{s}$. The significant differences of $Q$ between Hydro Survey Boat Version 1 as $0.0853 \mathrm{m3} / \mathrm{s}$ (56.3\%) and Hydro Survey Boat Version 2 as $0.042 \mathrm{m3} / \mathrm{s}(11.2 \%)$ which is the Hydro Survey Boat Version 2 recorded more accurate readings compared Hydro Survey Boat Version 1. There are several advantages of this project which is reducing cost, improve efficiency, and reduce risk during hydrology survey. The development survey boat USV is innovation technology and it will improved the hydrological method.

Index Terms:- Current meter, hydrological survey, hydro survey boat, river discharge (Q), Unmanned Surface Vehicle $(\boldsymbol{U S V})$.
\end{abstract}

Revised Manuscript Received on July 10, 2019

Mohd Khairul Amri Kamarudin, Faculty of Applied Social Science (FSSG) and East Coast Environmental Research Institute (ESERI), Universiti Sultan Zainal Abidin, Gong Badak Campus, 21300 Terengganu, Malaysia.

Mohammad Faezul Hakim Mustapha, Faculty of Applied Socia Sciences, Universiti Sultan Zainal Abidin, Gong Badak Campus, 21300 Kuala Nerus, Terengganu, Malaysia.

Noorjima Abd. Wahab, East Coast Environmental Research Institute (ESERI), Universiti Sultan Zainal Abidin, Gong Badak Campus, 21300 Kuala Nerus, Terengganu, Malaysia.

Muhammad Hafiz Md. Saad, East Coast Environmental Research Institute (ESERI), Universiti Sultan Zainal Abidin, Gong Badak Campus, 21300 Kuala Nerus, Terengganu, Malaysia.

Mohd Ekhwan Toriman, Faculty of Social Sciences and Humanities, Universiti Kebangsaan Malaysia, 43600, Bangi, Selangor, Malaysia

Firdaus Mohd Hamzah, Faculty of Engineering and Buil Environment, Universiti Kebangsaan Malaysia, 43600, Bangi, Selangor, Malaysia

Mohd Armi Abu Samah, Kulliyyah of Science, International Islamic University Malaysia, 25200 Kuantan, Pahang, Malaysia

Mohd Syaiful Nizam Abu Hassan, Faculty of Applied Social Sciences, Universiti Sultan Zainal Abidin, Gong Badak Campus, 21300 Kuala Nerus, Terengganu, Malaysia.

Siti Nor Aisyah Md Bati, East Coast Environmental Research Institute (ESERI), Universiti Sultan Zainal Abidin, Gong Badak Campus, 21300 Kuala Nerus, Terengganu, Malaysia.

\section{INTRODUCTION}

As populations continue to enlarge, the number of competing and conflicting uses associated with our rivers will increase, rivers have been the focus of development over time such as understanding of the naturally stable character of the river is necessary if maintenance of its function and health is to be secured. In fact, people should realize that our river needs to be taken care of and should have an effort to improve the river. Recently, the river restoration projects and naturalization applications in developed countries to improve, mitigate, or to enhance lost water resource values [1]-[3]. A lot of many have been spent in recent years on rivers to improve stability, fish habitat, visual values, flood control works, and a multitudinous array of manufactured improvements [4]. Studying the hydrographic is one of the standard procedure employed by scientists and engineers to identify the natural and altered sea or river nature systems, make sure that the free of major maintenance problems and landing is easy to use [5]-[9]. In Canada, attempts have been made to follow the Scandinavian example, but it has been discovered hard to build up the reliability of equipment which is necessary for the method, and on Canada's east coast the conditions of the sea are considerably more severe than in the Baltic and the eastern North Sea. The issue of equipment reliability can most likely overcome, but the problem of sea state, basically in the wide areas, requires a new approach [10].

Hydrology is the logical research of the advancement, circulation, and nature of water on Earth in different planets, including the water cycle, water resource, and biological watershed sustainability. A specialist of hydrology is known as a hydrologist, working in the fields of earth or ecological science, physical geology, topography or common and natural designing. Many several basic methods have been used by researchers in conducting research related to hydrology. Among the study carried out by researchers usually is to collect data size and continuity of the river. People realize that the river size is its width but the channel width is not the only measure of river size. The depth of streamflow is also a measure of river size, and we can go

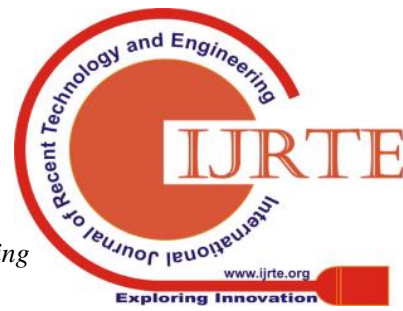




\section{ASSESSMENT OF HYDROLOGICAL INSPECTION USING DEVELOPMENT LOW-COST BOAT APPLICATION IN UNIVERSITY SULTAN ZAINAL ABIDIN (UNISZA) LAKE, TERENGGANU, MALAYSIA}

through the small river, but for a large river, we need to cross by boat or bridge. Another method to determine the stream size is the cross-sectional area of the channel. However, another method to measure the river size is the volume of water that totally possesses the channel and the streamflow [11]-[14].

There is a specific aim of hydrographic survey, using any method such as sonic depth measurement and running parallel sounding lines over the area, has to be formulated regarding the desired accuracy criterion [15]. Another technique of hydro surveying used to examine underwater environment was based on RTK/DGPS technology, side scan sonar (SSS), single beam echo sounders (SBES), and direct underwater research. It makes conceivable route of the small hydrographic vessel along the pre-characterized profiles, examination of base shape, measure of water volume, elaboration of stream charts and observing of unsafe shallow spots [16]. All of this technology is typically seen in other countries but fewer in Malaysia. Typically, the price of a bigger boat and UAV is expensive, the conventional boat is less efficiency and logistic cost is high to conduct research studies. The manual operated boat is very dangerous and can cause accidents to the researcher during the research process. The aim of design and develop low-cost prototype boat for to collect data for water discharge by measuring water depth, water velocity and river width for hydro survey. The hydro survey boat project for measuring river environment could increase the total productivity of that human labour, and thereby reduce ecological damage and avoid an accident during researching on site. Besides, to minimizing environmental and human cost, the low-cost automatic boat can benefit the user for by increasing the accuracy of collecting data. Otherwise, the impact or usefulness for this project is researcher and educators in hydrology field around country can benefit this product for research and development program.

\section{LITERATURE VIEW}

Based on river formation concept, a basic control on river size is the discharge, and the discharge measurement depends on the flow velocity measurement. The equation continuity relation $\mathrm{Q}=\mathrm{AV}$ is based on the river flow measurement, water discharge $(\mathrm{V})$, cross-sectional area $(\mathrm{A})$, and flow velocity $(\mathrm{V})$. The cross-section of the channel must be observed to determine the cross-sectional area (A), and the average of flow velocity $(\mathrm{V})$ is determined by using a current meter [17], [18]. Practically, dividing the crosssection of the channel into a number subsection and measuring the discharge in each and summing them is how to determine discharge of water. This method is known as component method (Fig. 1 and 2).

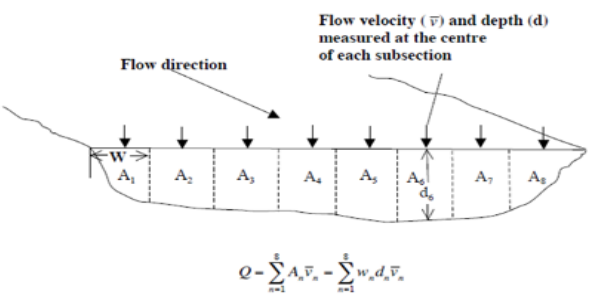

Fig. 1: Theoretical method of measuring river discharge

(Q)

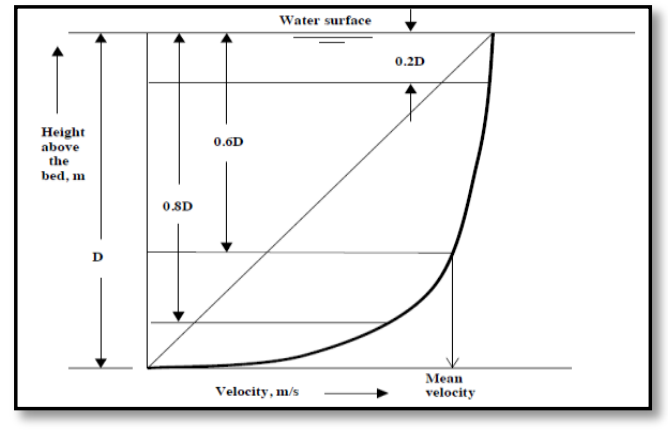

Profile of velocity in a river channel

Fig. 2:

There are various types of boat surveys available in the market today in terms of good quality and advanced technology. The function applied to the boat also is suitable and appropriate for use in the study of hydrology. Based on studies that have been conducted, most of the survey boat has a price that is too expensive and unaffordable by a few researchers in Malaysia. Mostly the survey boat has a price in the range of up to RM200000. The price will be a problem for researchers in Malaysia in the process of implementing the study of rivers across the country. The sizes and materials used to make boats is also very important in determining whether the boat is expensive or inexpensive. So, at the end of this project, the researcher expects this product to be produced will help researchers in order to have a survey boat at low cost and good quality. Based on previous studies that have been described in detail previously, some of the existing concept can be considered and used to developing this project such as electronic component for boat moving operation to collect data. To achieve the objectives which focus on cost reduction, material used, small-scale size, it is better to implement the innovation of existing method, design, and technology into the product to be produced.

\section{THEORETICAL FRAMEWORK}

University Sultan Zainal Abidin (UniSZA) Lake was selected as the study area to test the product development process, the fabrication of Hydro Survey Boat is due to the inefficiency of manual boat during hydrology process. This is because the manual boat is expensive in terms of logistic and dangerous to the researcher during hydrology survey. The methodology is a system of methods used in finishing this project. In design and prototype low-cost boat for hydro survey, there are several steps must be followed. So, a flow chart is charted out as a guideline to be followed. Besides knowing procedure of project, the procedure of designing and fabricating should be known very well. It will produce the product better. There are several methods involves finding the information about this project. Other than that, it can help the researcher to get the correct statement and information about their research and also help to create a product by searching the difficulties. Besides that, identifying the problems can facilitate the generation of 
many ideas to produce the product. Not only have that, the researcher can fulfil the user requirement as well as to innovate the hydro survey boat. A few methods provided to the information about this project such as observation, interview, and literature review. There are three steps in design stage which are sketching, evaluating and 3D drawing. Meanwhile, fabrication has a few steps. Based on the below, the research model can be described as Fig. 3 .

Evaluation is based on the concept hydro survey boat had been proposed. From these sketches, an evaluation is made to evaluate the best concept or combine the concept. After the process of sketching and evaluation, the selected design for boat is as below (Fig. 4). There are different criteria in the matrix chart includes lightweight, durability, ease of manufacture, ease of handling, ease of use, material cost and safety. For the selected design, 3D drawing is produced through running out the Autodesk Inventor software. Every part has been sketched then assembled through the inventor software. This stage is important to get a preliminary view of the product to be developed. Then the assembled product has been applied through 2D drawing to show the different view includes top front view, top view, side view, and isometric view (Fig. 5). Every part has been sketched then assembled through the inventor software. This stage is important to get a preliminary view of the product to be developed. Then the assembled product has been applied through 2D drawing to show the different view includes top front view, top view, side view, and isometric view (Fig. 6).

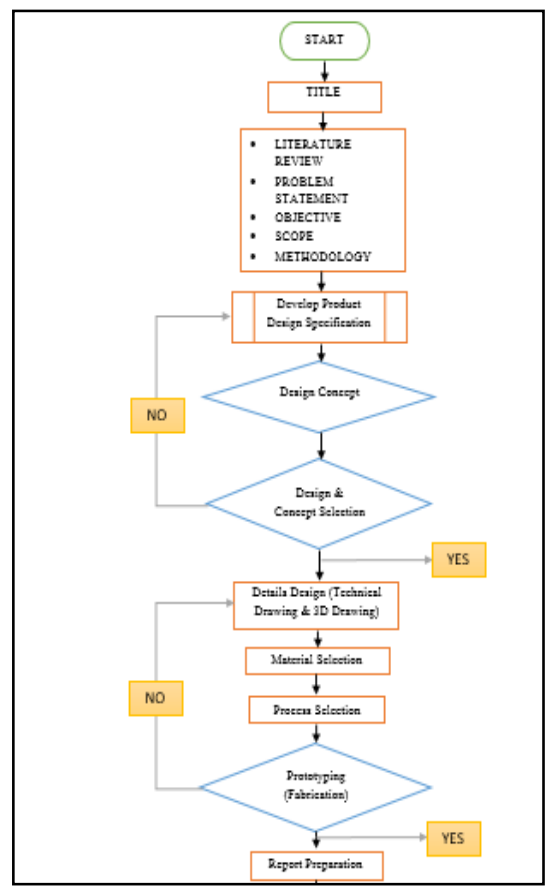

Fig. 3: The framework of studies

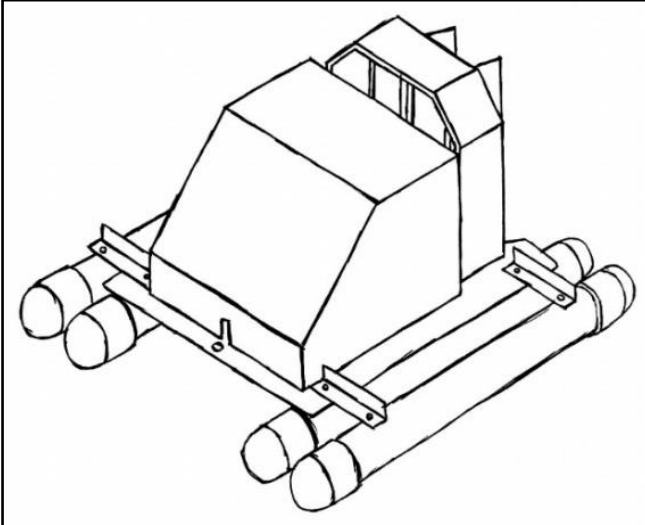

Fig. 4: Selected design

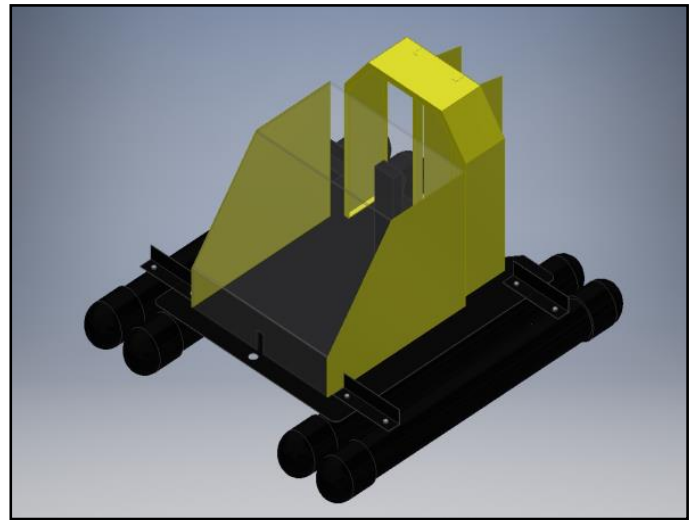

Fig. 5: 3D drawing of selected design

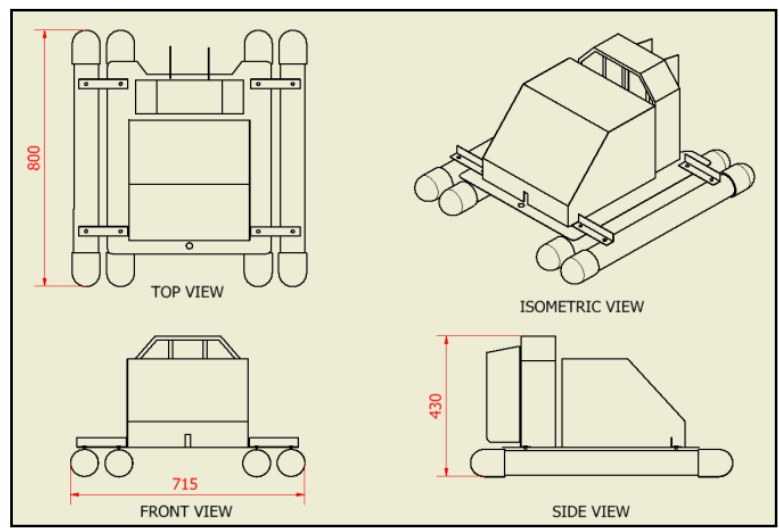

Fig. 6: Technical drawing with dimension

Product architecture is related to the functional elements and physical components of products [19]. The scheme by which the function of a product is allocated to physical components, more precisely as the arrangement of functional elements, the mapping from functional elements to physical components, and the specification of the interfaces among interacting physical components [20]. The arrangement of functional elements into physical chunks which become the building blocks for the product or family of products. Fig. 7 shows the parts of the boat details with the description. There are five types of material will be use based on material cost, manufacturing cost and quality that lasts longer after product is developed, which are Polyvinyl

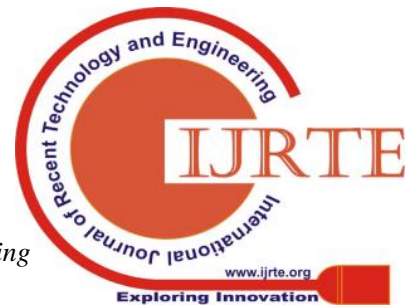




\section{ASSESSMENT OF HYDROLOGICAL INSPECTION USING DEVELOPMENT LOW-COST BOAT APPLICATION IN UNIVERSITY SULTAN ZAINAL ABIDIN (UNISZA) LAKE, TERENGGANU, MALAYSIA}

Chloride (PVC), perspex, sheet metal and aluminium. PVC are often lighter, less expensive. PVC provide smoother wall surfaces that reduce fluid friction and resistance to flow. The physical properties of PVC allow designers and specifiers a high degree of freedom when designing products where PVC acts as a replacement or refurbishment. The Poly (methyl methacrylate) (PMMA), also known as acrylic or acrylic glass as well as by the trade names Crylux, Plexiglas, Acrylite, Lucite, and Perspex, is a transparent thermoplastic often used in sheet form as a lightweight or shatter-resistant alternative to glass [21]. Then, the sheet metal is metal formed by an industrial process into thin, flat pieces. Sheet metal is one of the fundamental forms used in metalworking and it can be cut and bent into a variety of shapes. Sheet metal is available in flat pieces or coiled strips [22]. Then, the aluminium bar is a solid wrought product that is long in length in relation to its small cross-sectional dimensions. Aluminium is a lightweight for their size. They also have a very thin layer of their oxides on the surface, which stops air and water getting to the metal, so aluminium resist corrosion. These properties make the two metals very useful [23] (Fig. 8).

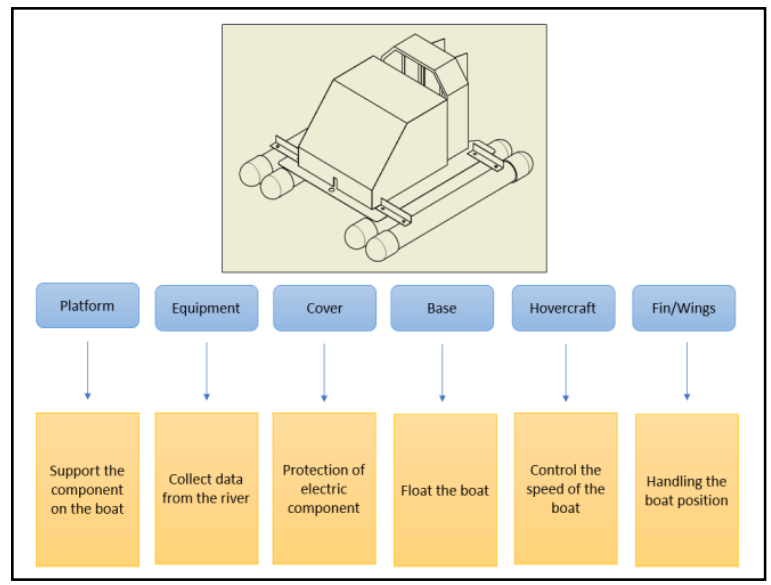

Fig. 7: Modular architecture based on selected design

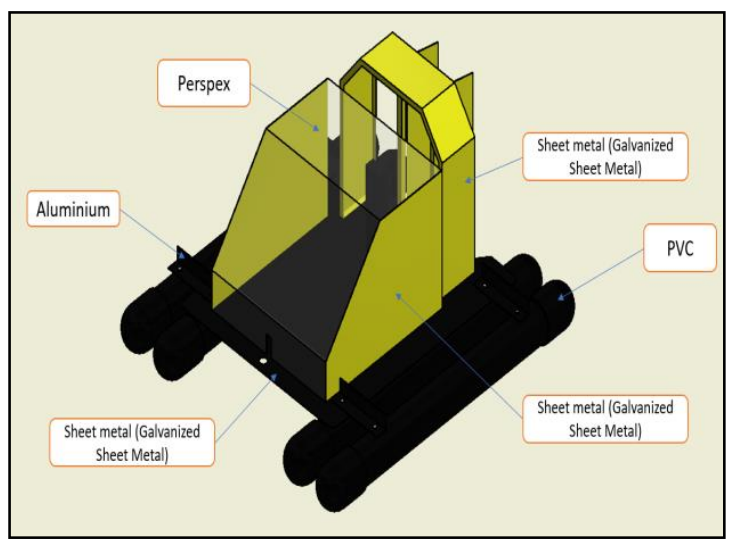

Fig. 8: Material used to fabricate the boat

In term of production quantity, the fabrication process is different from the manufacturing process. The fabrication process is a process to make only one product rather than manufacturing process that focus on large-scale production. In the low-cost for hydro survey project, fabrication is use for the whole process. In the making of boat design to become a real product, several processes have been used to fabricate the boat. There are several steps for boat making process. The base of the boat is made using PVC pipes to float the boat. Aluminum bars (U-channel) are cut into desire dimension of the boat as support between platform and pipes. The platform of the boat is build using a flat sheet metal (Galvanized) and mounted on the top of the pipes. Assemble the RC component such as, propeller motor, servo and battery on the boat. The next step is fabricating the housing part. This complex part was create using sheet metal. Bending machine was used to bend the sheet metal to shape an angle of the housing. To strengthen the housing, aluminium U-channel is used to support of the housing angle. Then, the housing part was assembled to the platform of the boat. The next fabrication is wing which is using the sheet metal. There are two wings attached to the housing that are located at the back of the boat. Then, the electronic component is installed such as ESC (Electronic Speed Controller) BEC (Battery Eliminator Circuit). The next step is fabricating the boat cover. The sheet metal is cut into two pieces according to the specified dimension. Then, cut the Perspex to make the front and top cover of the boat. Next, two more pipes are attached to get more balance during testing. The hydrology equipment is also one of the factors for the addition of a pipe on the boat. Finally, all parts of the boat are sprayed with black and yellow colors. Then, the boat were tested to collect data (Fig. 9). There are several stages involve in such as designing process, material selection, project costing, and tools or equipment could be used to develop the product. There are some problems occur but had been solved at the end of the fabrication process [24]-[26]. The expected result for this study is hydro survey boat can give the best performance during the process of collecting data (environmental impact assessment) [27][30]. Moreover, the hydro survey boat can give a huge impact in terms of safety to the user compared to the manual boat.

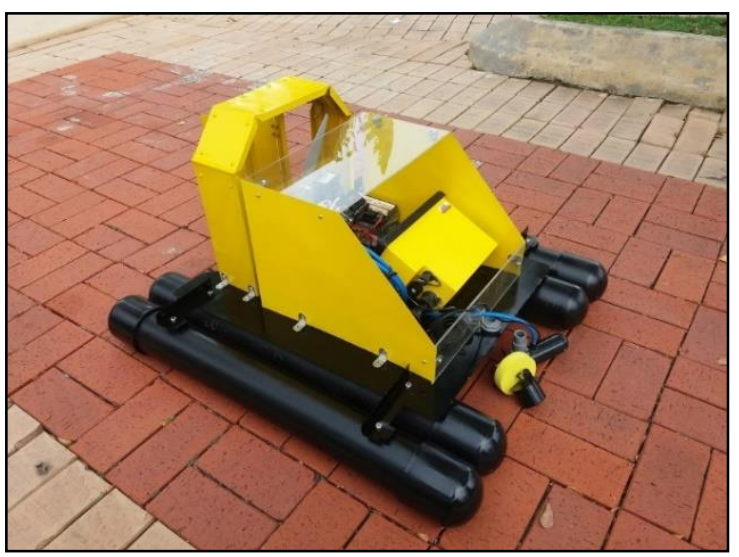

Fig. 9: Final Product

\section{RESULTS AND DISCUSSION}

In the product development process, the fabrication of Hydro Survey Boat is due to the inefficiency of manual boat during hydrology process. This is because the manual boat is expensive in terms of logistic and dangerous to the

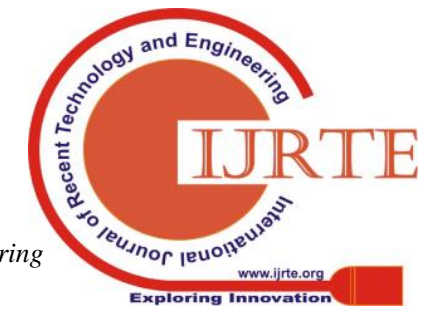


researcher during hydrology survey (Fig. 10). Because there is a weakness of manual boat, the researcher get an idea to develop the low cost hydro survey boat. The first edition of the boat was called Boat Version 1 has been developed using low cost material as a testing product (Fig. 11). After the Boat Version 1 was produced, there were some improvements that needed to be made, especially in terms of the balance and strength of the boat body. This problem has been identified during the test in the UniSZA lakes. The heavier hydrographs as compared to the buoyancy at the bottom of the boat have resulted in imbalances when researchers controlled bots. Boat speed is also limited when the water floods the front of the boat. So, the researcher have developed the Boat Version 2 by improving the disadvantages of Boat Version 1 to ensure the objectives of this study can be achieved (Fig. 12).

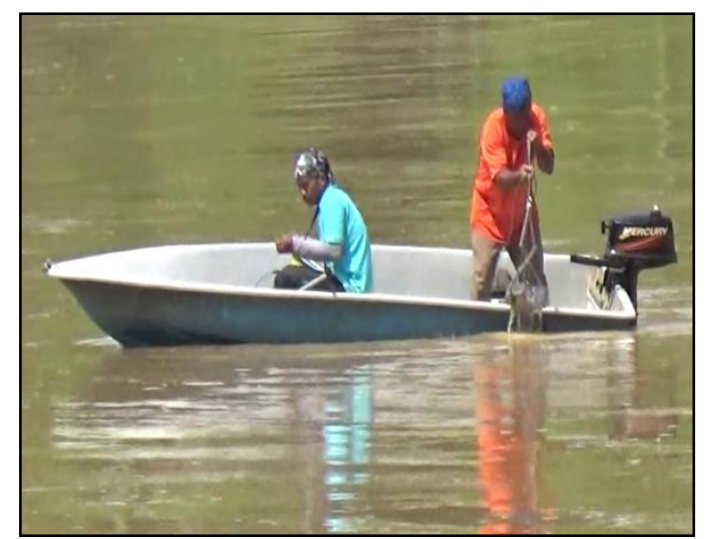

Fig. 10: Dangerous position of researcher on the boat

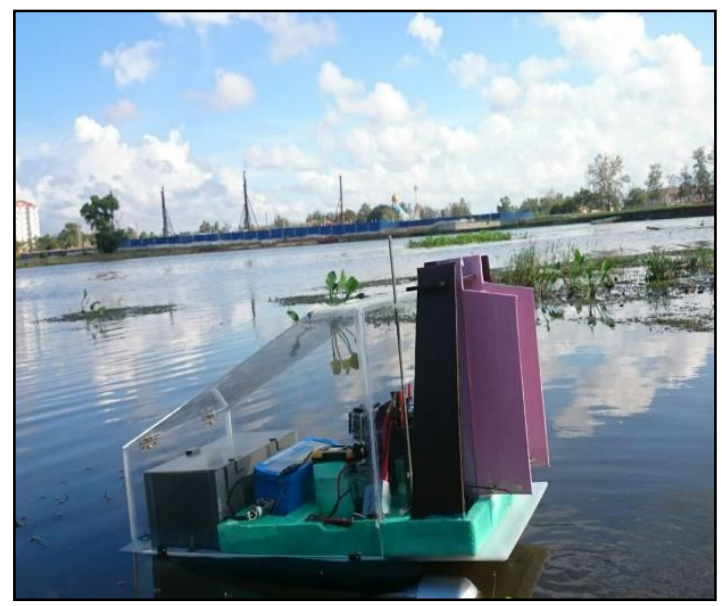

Fig. 11: The first product (Boat Version 1)

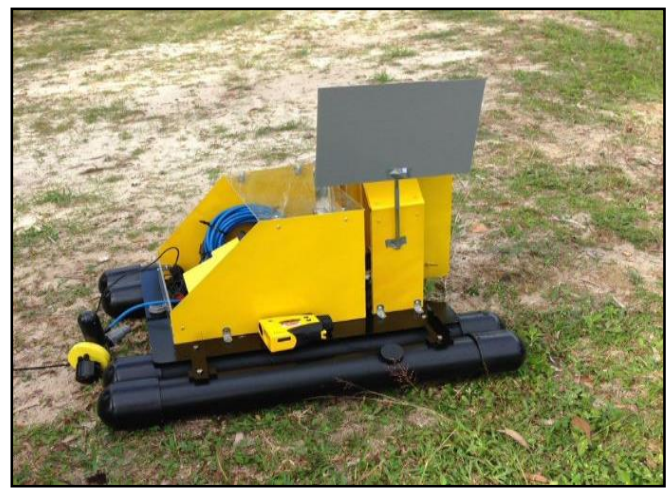

Fig. 12: Boat Version 2
This testing is to show the differences between three factors which is cost, manpower, and time consume during hydrology survey work. With supply voltage 12 Volt DC, the boat version 2 is controlled by one operator and the operational distance for this test is 15 meter alongside the river to see the balancing and handling of the boat. The same testing which is floating test was conducted to the boat version 1 before renovate this boat. Below is the data collected then formed on the Table 1. This table show three important factors including cost, manpower and time. The cost (RM) refer to the cost of logistic and cost during survey was conducted. The manpower refer to the number of staff and for time (hours) refer to the time consume for one station during hydro survey work.

Table 1: Data collection of cost (RM), manpower and time

\begin{tabular}{|c|c|c|c|}
\hline & $\begin{array}{c}\text { Cost } \\
(\mathrm{RM})\end{array}$ & Manpower & $\begin{array}{c}\text { Time } \\
\text { (Hours) }\end{array}$ \\
\hline Manual & 50 & 5 & 3 \\
\hline Boat Version 1 & 30 & 2 & 1.5 \\
\hline Boat Version 2 & 15 & 1 & 1 \\
\hline
\end{tabular}

Based on Fig. 13, cost of manual method is the highest than method using boat version 1 and boat version 2 . This is because the surveyor need to rent a truck or 4WD car for transportation to transfer the bigger boat to the field work. It can cause more money will be spent for this operation. The time consume by using the conventional boat also highest. The trend in the graph shows that the latest development product which is boat version 2 is more relevant to be used in hydro survey work based on aspect low-cost, less manpower, and less time consume. The benchmark for boat version 1 and boat version 2 in this testing is the manual method. The result was translate into the graph to make comparison between three validation of data collection by using manual method, Boat Version 1, and Boat Version 2. The data collection were included width (river crosssection), depth, and velocity of the river. Table 2, Table 3 , Table 4 show the data collection using manual method, boat version 1 and boat version 2 . Then, Table 5 to make a comparison between manual method, Boat version 1, and Boat version 2.

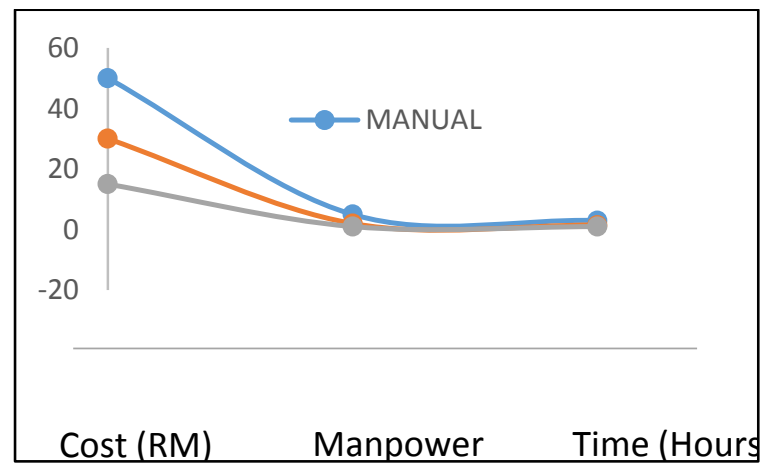

Fig. 13: Graph of cost (RM), manpower and time (hours) 
ASSESSMENT OF HYDROLOGICAL INSPECTION USING DEVELOPMENT LOW-COST BOAT APPLICATION IN UNIVERSITY SULTAN ZAINAL ABIDIN (UNISZA) LAKE, TERENGGANU, MALAYSIA

Table 2: Data collection using manual method

\begin{tabular}{|c|c|c|c|c|c|c|}
\hline \multicolumn{7}{|c|}{ LEFT > RIGHT } \\
\hline Width (m) & $1^{*}$ & 2 & 4 & 6 & $8^{*}$ & 10 \\
\hline Depth (m) & 0 & 0.5 & 0.8 & 0.71 & 0 & 0 \\
\hline Velocity (m/s) & 0 & 0.029 & 0.01 & 0.024 & 0 & 0 \\
\hline
\end{tabular}

\begin{tabular}{|c|c|c|}
\hline Q1: A1xV1 $=$ & $0.5 \times 1 \times 0.5 \times 0.029=$ & 0.0073 \\
\hline Q2: A2xV2 $=$ & $0.5(0.8+0.5) 2 \times 0.01=$ & 0.013 \\
\hline Q3: A3xV3 $=$ & $0.5 \times 2 \times 0.71 \times 0.024=$ & 0.017 \\
\hline DISCHARGE & Q1+Q2+Q3= & 0.0373 \\
\hline
\end{tabular}

Table 3: Data collection using Boat Version 1

\begin{tabular}{|c|c|c|c|c|c|c|}
\hline \multicolumn{7}{|c|}{ LEFT > RIGHT } \\
\hline Width (m) & $1^{*}$ & 2 & 4 & 6 & $8^{*}$ & 10 \\
\hline Depth & 0 & 0.5 & 0.75 & 0.71 & 0 & 0 \\
\hline Velocity (m/s) & 0 & 0.153 & 0.023 & 0.026 & 0 & 0 \\
\hline
\end{tabular}

\begin{tabular}{|c|c|c|}
\hline $\mathrm{Q} 1: \mathrm{A} 1 \times \mathrm{V} 1=$ & $0.5 \times 1 \times 0.5 \times 0.153=$ & 0.038 \\
\hline $\mathrm{Q} 2: \mathrm{A} 2 \times \mathrm{V} 2=$ & $0.5(0.75+0.5) 2 \times 0.023=$ & 0.0288 \\
\hline $\mathrm{Q} 3: \mathrm{A} 3 \times \mathrm{V} 3=$ & $0.5 \times 2 \times 0.71 \times 0.026=$ & 0.0185 \\
\hline DISCHARGE & $\mathrm{Q} 1+\mathrm{Q} 2+\mathrm{Q} 3=$ & 0.0853 \\
\hline
\end{tabular}

Table 4: Data collection using Boat Version 2

\begin{tabular}{|c|c|c|c|c|c|c|}
\hline \multicolumn{7}{|c|}{ LEFT > RIGHT } \\
\hline Width (m) & $1^{*}$ & 2 & 4 & 6 & $8^{*}$ & 10 \\
\hline Depth (m) & 0 & 0.5 & 0.79 & 0.71 & 0 & 0 \\
\hline Velocity (m/s) & 0 & 0.051 & 0.01 & 0.023 & 0 & 0 \\
\hline
\end{tabular}

\begin{tabular}{|c|c|c|}
\hline Q1: A1 $1 \times 1=$ & $0.5 \times 1 \times 0.5 \times 0.051=$ & 0.013 \\
\hline Q2: A2xV2 $=$ & $0.5(0.79+0.5) 2 \times 0.01=$ & 0.013 \\
\hline Q3: A3xV3 $=$ & $0.5 \times 2 \times 0.71 \times 0.023=$ & 0.016 \\
\hline DISCHARGE & Q1+Q2+Q3= & 0.042 \\
\hline
\end{tabular}

Table 5: Data collection of equipment validation

\begin{tabular}{|c|c|c|c|}
\hline & $\begin{array}{c}\text { Depth } \\
(\mathrm{m})\end{array}$ & $\begin{array}{c}\text { Velocity } \\
(\mathrm{m} / \mathrm{s})\end{array}$ & $\begin{array}{c}\mathrm{Q} \\
\left(\mathrm{m}^{3} / \mathrm{s}\right)\end{array}$ \\
\hline MANUAL & 0.8 & 0.029 & 0.0373 \\
\hline BOAT VERSION 1 & 0.75 & 0.153 & 0.0853 \\
\hline BOAT VERSION 2 & 0.79 & 0.051 & 0.042 \\
\hline
\end{tabular}

Based on Fig. 14, it is found that there is significant difference between Boat Version 1 and manual method. The measurement reading for depth is 0.05 meter lower than manual method. The measurement reading for velocity of Boat Version 1 is 0.123 higher that manual method. It is found that the Boat Version 1 is unstable and unbalance during testing. The front part of the boat that hold the sonar (to measure the depth), the current meter sensor are too much weight and effect the boat stability. Then, some renovation have been made to Boat Version 2, the result is quite accurate with manual method. The depth reading is 0.079 meter, 0.01 meter lower than manual method. The velocity reading is $0.051,0.022$ higher than manual method. So, the graph conclude that the Boat Version 2 testing equipment is more valid than Boat Version 1.

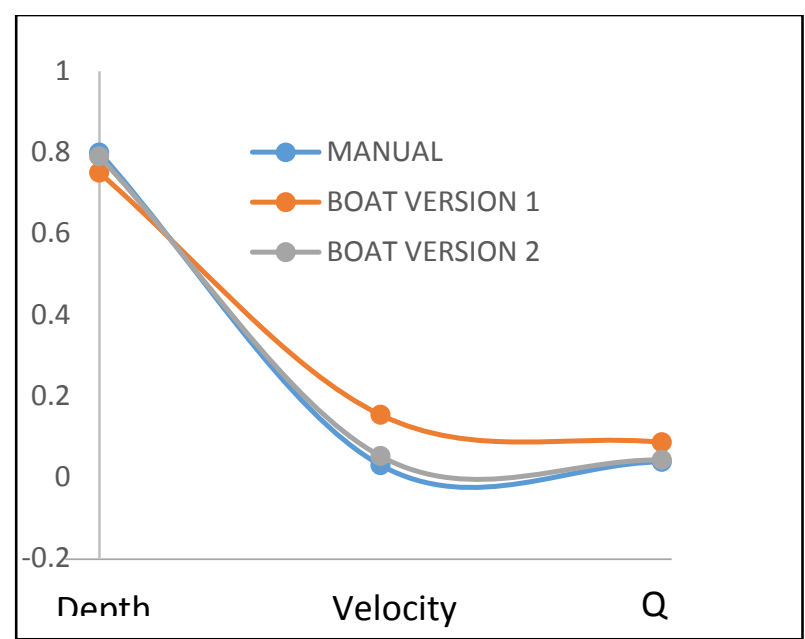

Fig. 14: The equipment validation

\section{CONCLUSION}

The river restoration projects and naturalization applications in developed countries to improve, mitigate, or to enhance lost water resource values. in fact, people should realize that our river needs to be taken care of and should have an effort to improve the river. this study improved the balancing and stability of the boat to get more accurate data as manual method during hydro survey process. the better result gets from this study in terms of cost, manpower, time consume after several improvements. the hydro survey boat project for measuring river environment could increase the total productivity of that human labor, and thereby reduce ecological damage and avoid an accident during researching on site. besides, to minimizing environmental and human cost, the low-cost automatic boat can benefit the user for by increasing the accuracy of collecting data.

\section{ACKNOWLEDGMENT}

The author would like to thank $\mathrm{kpm}$ for providing financial sup-port for this research on the srgs: pembangunan pemodelan luahan persekitaran ekohidrologi di tasik kenyir, hulu terengganu, terengganu. (unisza/2017/srgs/17) - r0019-r017, frgs 2017 potential effects of climate change on streamflow, based on the occurrence of severe floods in east and west coasts of malaysia peninsular river basins (frgs/1/2017/wab05/unisza/01/ 1) - rr22 and department of irrigation and drain-age malaysia for the secondary data and east coast environmental research institute (eseri), universiti sultan zainal abidin (unisza) give permission to use research facilities and supporting in this research.

\section{REFERENCES}

1. M. K. A. Kamarudin, M. E. Toriman, N. A. Wahab, H. Juahir, A. Endut, R. Umar, and M. B. Gasim, "Development of stream classification system on tropical areas with statistical approval in Pahang River Basin, Malaysia," Desalination and Water Treatment, 96, 2017, pp. 237-254. 
2. H. Juahir, M. B. Gasim, M. K. A. Kamarudin, A. Azid, N. S. Hairoma, M. H. M. Saad, and M. Mokhtar, "Assessment by multivariate analysis of groundwater between low and high tides interactions in east coast of Terengganu," International Journal of Engineering and Technology, 7(3.14), 2018, pp. 80-84.

3. I. M. Sujaul, M. I. Ali, N. I. Ramli, M. E. Toriman, M. K. A. Kamarudin, H. Juahir, and M. B. Gasim, "Spatial variation characteristics of selected soils in the Tasik Chini Watershed, Pahang, Malaysia," International Journal of Engineering and Technology, 7(3.14), 2018, pp. 360-365.

4. D. L. Rosgen, Applied River Morphology. Colorado: Wildland Hydrology, 1996.

5. J. MacMahan, "Hydrographic surveying from personal watercraft," Journal of Surveying Engineering, 127(1), 2001, pp. 12-24.

6. J. A. Sciortino, Fishing Harbour Planning, Construction and Management. Rome: Food and Agriculture Organization of the United Nations, 2010.

7. M. E. Toriman, M. K. A. Kamarudin, M. B. Gasim, J. Mokhtar, N. A. A. Azlina, and P. Lun, "Water quality status and hydrological analysis in upper tropical river, Malaysia," International Journal of Agriculture and Crop Science, 4(2), 2012, pp. 33-39.

8. A. S. M. Saudi, M. K. A. Kamarudin, I. S. D. Ridzuan, R. Ishak, A. Azid, and Z. I. Rizman, "Flood risk index pattern assessment: Case study in Langat river basin," Journal of Fundamental and Applied Sciences, 9(2S), 2017, pp. 12-27.

9. N. H. Sulaiman, M. K. A. Kamarudin, M. E. Toriman, H. Juahir, F. M. Ata, A. Azid, and A. Arfan, "Relationship of rainfall distribution and water level on major flood 2014 in Pahang River Basin, Malaysia," EnvironmentAsia, 10(1), 2017, pp. 1-8.

10.A. J. Kerr, and D. F. Dinn, The use of robots in hydrography," International Hydrographic Review, 62(1), 2015, pp. 41-52.

11. M. E. Toriman, M. K. A. Kamarudin, M. Idris, N. R. Jamil, M. B. Gazim, and N. A. A. Aziz, "Sediment concentration and load analyses at Chini River, Pekan, Pahang Malaysia," Research Journal of Earth Sciences, 1(2), 2009, pp. 43-50.

12. M. E. Toriman, F. M. Ata, M. K. A. Kamarudin, and M. Idris, "Bed-load sediment profile and effect of river bank erosion on river cross-section," American Journal of Environmental Sciences, 9(4), 2013, pp. 292-300.

13.M. K. A. Kamarudin, M. E. Toriman, M. H. Rosli, H. Juahir, N. A. A. Aziz, A. Azid, S. F. M. Zainuddin, and W. N. A. Sulaiman, "Analysis of meander evolution studies on effect from land use and climate change at the upstream reach of the Pahang River, Malaysia," Mitigation and Adaptation Strategies for Global Change, 20(8), 2015, pp. 1319-1334.

14.F. M. Ata, M. K. A. Kamarudin, N. Yaakub, N. A. Wahab, M. E. Toriman, H. Juahir, M. B. Gasim, Sunardi, A. A. A. Halim, M. N. A. A. Raoff, and M. N. Haris, "Impact of hydrological study to water quality status in Kuantan River, Pahang, Malaysia," International Journal of Engineering and Technology, 7(3.14), 2018, pp. 3543.
15.E. C. Bouwmeester, and A. W. Heemink, "Optimal line spacing in hydrographic survey," International Hydrographic Review, 70(1), 1993, pp. 37-48.

16.D. Popielarczyk, "Application of global navigation satellite system and hydroacoustic techniques to safety of inland water navigation," Archives of Transport, 23(2), 2011, pp. 191-207.

17. M. K. A. Kamarudin, M. E. Toriman, N. H. Sulaiman, F. M. Ata, M. B. Gasim, A. Muhamad, W. A. Yusoff, M. Mokhtar, M. A. Amran, and N. A. A. Aziz, "Classification of tropical river using chemometrics technique: Case study in Pahang River, Malaysia," Malaysian Journal of Analytical Sciences, 19(5), 2015, pp. 1001-1018.

18. N. A. Wahab, M. K. A. Kamarudin, A. Anuar, F. M. Ata, N. H. Sulaiman, N. B. Baharim, N. S. Harun, and N. A. Muhammad, "Assessments of lake profiling on temperature, Total Suspended Solid (TSS) and turbidity in the Kenyir Lake, Terengganu, Malaysia," Journal of Fundamental and Applied Sciences, 9(2S), 2017, pp. 256-278.

19.K. T. Ulrich, Product Design and Development. Telangana: Tata McGraw-Hill Education, 2003.

20.K. Ulrich, "The role of product architecture in the manufacturing firm," Research Policy, 24(3), 1995, pp. 419-440.

21. M. Berins, Plastics Engineering Handbook of the Society of the Plastics Industry. Berlin: Springer Science and Business Media, 1991.

22.V. S. Lodhi, and P. A. K. Jain, "A review of experimental study of spring back effect of aluminum sheet metal," International Journal of Engineering Sciences and Research Technology, 3(4), 2014, pp. 8033-8036.

23. J. R. Davis, Alloying: Understanding the Basics. Ohio: ASM International, 2001.

24.L. Amelia, D. A. Wahab, C. H. C. Haron, N. Muhamad, and C. H. Azhari, "Initiating automotive component reuse in Malaysia," Journal of Cleaner Production, 17(17), 2009, pp. 1572-1579.

25.N. Subramanian, and R. Ramanathan, "A review of applications of Analytic Hierarchy Process in operations management," International Journal of Production Economics, 138(2), 2012, pp. 215-241.

26. M. Chavan, "An appraisal of environment management systems: A competitive advantage for small businesses," Management of Environmental Quality: An International Journal, 16(5), 2005, pp. 444-463.

27. M. K. A. Kamarudin, M. E. Toriman, H. Juahir, A. Azid, M. B. Gasim, A. S. M. Saudi, R. Umar, N. H. Sulaiman, F. M. Ata, A. M. Mustafa, and M. A. Amran, "Assessment of river plan change using RS and GIS technique," Jurnal Teknologi, 76(1), 2015, pp. 31-38.

28. A. Azid, H. Juahir, M. E. Toriman, A. Endut, M. K. A. Kamarudin, A. Rahman, and M. Nordin. "Source apportionment of air pollution: A case study in Malaysia," Jurnal Teknologi, 72(1), 2015, pp. 83-88. 


\section{ASSESSMENT OF HYDROLOGICAL INSPECTION USING DEVELOPMENT LOW-COST BOAT APPLICATION IN UNIVERSITY SULTAN ZAINAL ABIDIN (UNISZA) LAKE, TERENGGANU, MALAYSIA}

29. O. Jaafar, M. E. Toriman, M. Idris, S. M. S. Abdullah, H. Juahir, N. A. A. Aziz, M. K. A. Kamarudin, and N. R. Jamil, "Study of water level-discharge relationship using artificial neural network (ANN) in Sungai Gumum, Tasik Chini Pahang Malaysia," Research Journal of Applied Sciences, 5(1), 2010, pp. 20-26.

30. M. E. Toriman, M. B. Gasim, Y. Zulkifli, S. Ismail, S. A. Sharifah Mastura, A. Pauzi, J. Mokhtar, A. Nor, M. K. A. Kamarudin, J. Othman, and K. Othman, "Use of $137 \mathrm{Cs}$ activity to investigate sediment movement and transport modeling in river coastal environment," American Journal of Environmental Sciences, 8(4), 2012, pp. 417-423. 